\title{
PROBIOTIK: PEMANFAATANNYA UNTUK PAKAN IKAN BERKUALITAS RENDAH
}

\author{
Abdul Mansyur') dan Abdul Malik Tangko*) \\ *) Balai Riset Perikanan Budidaya Air Payau, Maros
}

\begin{abstract}
ABSTRAK
Probiotik mempunyai prospek yang cerah dalam membantu memperbaiki pakan berkualitas rendah pada budidaya ikan sehingga akan ikut meningkatkan produktivitas perikanan budidaya. Salah satu jenis probiotik yang telah dicoba adalah probiotik dengan merek dagang $\mathrm{H}-\mathrm{S}$ dicampurkan ke dalam pakan dengan menggunakan hewan uji ikan bandeng dal am kerambajaring apung (KJA) di laut ukuran $1 \mathrm{~m} \times 1 \mathrm{~m} \times 1,2 \mathrm{~m}$. Dari hasil ujicoba menunjukkan bahwa dengan konsentrasi $0,2 \% \mathrm{~kg}$ pakan yang diberikan pada hewan uji ikan bandeng memberikan respons yang terbaik terhadap laju pertumbuhan harian, rasio konversi pakan, dan kecernaan pakan baik bahan kering, protein, maupun energi.
\end{abstract}

KATA KUNCl: probiotik, budidaya, pakan, ikan

\section{PENDAHULUAN}

Dalam usaha budidaya, peningkatan produksi dapat dicapai dengan cara mengoptimalkan kondisi lingkungan, mendapatkan padat tebar yang tepat, memperbaiki kualitas benih dan pemberian pakan berkualitas baik. Di samping itu, dapat pula dilakukan melalui upaya menurunkan tingkat mortalitas dan meningkatkan laju pertumbuhan individu.

Pada budidaya ikan secara intensif, pakan merupakan komponen biaya produksi yang paling tinggi yaitu $60 \%$ $70 \%$ dari biaya operasional. Hal ini disebabkan karena tingginya harga bahan baku pakan yang sampai saat ini sebagian besar masih diimpor.

Ada beberapa cara yang dilakukan untuk dapat menekan harga pakan untuk mengurangi atau mengganti bahan baku impor dengan bahan baku lokal antara lain: kepala udang, bungkil kelapa sawit, dedak, maupun limbah peternakan seperti darah hewan. Untuk memperbaiki kualitas bahan baku lokal perlu dikaji terlebih dahulu penambahan (suplemen) ke dalam pakan (bahan baku lokal) apakah dapat memberikan pengaruh terhadap kualitas pakan yang dihasilkan atau pengaruhnya terhadap pertumbuhan ikan/organisme peliharaan. Probiotik adalah salah satu alternatif untuk penambahan (suplemen) ke dalam pakan ikan budidaya.

\section{PENGERTIAN PROBIOTIK}

Menurut Fuller (1987), probiotik yaitu makanan tambahan (suplemen) berupa sel-sel mikroba hidup, yang memiliki pengaruh menguntungkan bagi hewan inang yang mengkonsumsinya melalui penyeimbangan flora mikroba intestinalnya. Selanjutnya Salminen et al. (1999) menyatakan bahwa probiotik merupakan segala bentuk preparasi sel mikroba (tidak selalu harus hidup) atau komponen sel-sel mikroba yang memiliki pengaruh menguntungkan bagi kesehatan dan kehidupan inang. Dari definisi tersebut, Irianto (2003) meredifinisikan bahwa probiotik yaitu suplementasi sel mikroba utuh (tidak harus hidup) atau komponen sel mikroba pada pakan atau lingkungan hidupnya, yang menguntungkan inang. Selanjutnya dikatakan bahwa dalam budidaya, penelitian mengenai kerja probiotik baru bersifat empirik atau bersifat dugaan. Ada tiga model kerja probiotik yaitu: 1) menekan populasi mikroba melalui kompetisi dengan memproduksi senyawa-senyawa antimikroba atau melalui kompetisi nutrisi dan tempat pelekatan di dinding intestinum, 2) merubah metabolisme mikrobial dengan meningkatkan atau menurunkan aktivitas enzim, dan 3) menstimulasi imunitas melalui peningkatan kadar antibodi atau aktivitas makrofag.

Penggunaan probiotik di dalam bidang budidaya bertujuan untuk menjaga keseimbangan mikroba dan pengendalian patogen dalam saluran pencernaan, air, serta lingkungan perairan melalui proses bio degradasi.

Penelitian penggunaan probiotik pada budidaya ikan maupun udang mulai banyak dilakukan misalnya penggunaan jenis Bacillus spp. sebagai prebion dapat digunakan untuk memperbaiki kualitas air melalui penyeimbangan populasi mikroba dan mengurangi jumlah patogen dan secara bersamaan mengurangi penggunaan senyawa-senyawa kimia dan meningkatkan pertumbuhan serta kesehatan hewan inang (Wang et al., 1999 dalam Irianto, 2003). 


\section{JENIS PROBIOTIK YANG DIGUNAKAN}

Ada beberapa produk probiotik yang banyak beredar di pasaran misalnya Super NB, Super PS, Actizym, Aqua10 Dry, Aqua Simba, dan EM4 (Effektif Mikroorganisme4). Penggunaan probiotik tersebut tergantung peruntukannya misalnya Super NB merupakan koloni bakteri Bacillus yang mampu menguraikan senyawa nitrit, Super PS yang merupakan koloni bakteri sulfur khemototrof seperti bakteri Thiobacillus mampu menguraikan senyawa $\mathrm{H}_{2} \mathrm{~S}$ yang bersifat toksik bagi udang, EM4 berguna untuk memperbaiki kualitas air pemeliharaan (Khasani, 2007).

Salah satu jenis probiotik komersial yang telah diujicobakan/digunakan adalah probiotik dengan nama dagang H-S produksi Yastar International Co. Ltd Singen Pharmaceutical Works, Taiwan. Bahan ini dominan mengandung bakteri Lactobacillus.

Bakteri ini merupakan salah satu mikroorganisme fermentasi, sehingga bila terdapat dalam bahan makanan atau pakan, maka akan dapat melakukan perbaikan mutu pakan sehingga dapat meningkatkan kecernaan yang pada gilirannya dapat meningkatkan pertumbuhan. Mikroorganisme ini juga banyak digunakan dalam industri makanan seperti pembuatan keju, yogurt dari susu, tempe, dan tape (Buckle et al., 1987) dengan komposisi seperti Tabel 1, diduga dapat digunakan sebagai suplemen yang dapat memperbaiki kualitas pakan, sehingga dapat meningkatkan kecernaan pakan khususnya pada ikan.

Tabel 1. Komposisi bahan dalam setiap gram $\mathrm{H}-\mathrm{S} / \mathrm{g}$

\begin{tabular}{lc}
\hline \multicolumn{1}{c}{ Komposisi } & Kandungan \\
\hline Pantotenate & $4 \times 10^{5}$ cell \\
Dextrose & $80 \mathrm{mg}$ \\
Ascorbic Acid & $30 \mathrm{mg}$ \\
Biodiastase & $15 \mathrm{mg}$ \\
Nicotinamide & $10 \mathrm{mg}$ \\
Lycine HCL & $10 \mathrm{mg}$ \\
Dibasic & $10 \mathrm{mg}$ \\
Dextrine & $10 \mathrm{mg}$ \\
Mononitrate & $2 \mathrm{mg}$ \\
Pantotenate & $2 \mathrm{mg}$ \\
Lactose & $1 \mathrm{mg}$ \\
Vitamin B & $1 \mathrm{mg}$ \\
Vitamin E & $1 \mathrm{mg}$ \\
Folic Asid & $0,5 \mathrm{mg}$ \\
Vitamin A & $2.500 \mathrm{lu}$ \\
Vitamin D & $200 \mathrm{lu}$ \\
\hline
\end{tabular}

Sumber: Yastar International Co. Ltd Singen Pharmaceutical Works, Taiwan
Palinggi (1993) mengatakan bahwa nilai kecernaan suatu bahan makanan menggambarkan kemampuan ikan dalam mencerna suatu makanan dan kecernaan itu sendiri ditentukan oleh kualitas makanan yang diberikan.

\section{BAGAIMANA PROBIOTIK DAPAT MENIMBULKAN EFESIENSI PAKAN}

Beberapa jenis bahan baku lokal yang tersedia dan harganya relatif murah untuk dijadikan sebagai bahan pengganti di antaranya kepala udang, bungkil kelapa sawit, dedak, maupun limbah peternakan seperti darah hewan (Ahmad et al., 2000). Dari penggunaan bahan baku lokal yang tersedia sebagai bahan pengganti bahan baku impor untuk pakan ikan, ternyata mampu menekan biaya pakan hingga $40 \%$ walaupun diakui bahwa kualitasya relatif lebih rendah jika dibandingkan dengan kualitas bahan baku impor (Palinggi, 1993; Laining \& Rachmansyah, 2002). Penyebab rendahnya kualitas bahan baku lokal sebagai bahan pakan ikan, diduga disebabkan bahan dasar yang berbeda serta proses penanganannya, mulai dari penyiapan bahan sampai pembuatan bahan baku yang belum sempurna.

M enurut Irianto (2004), untuk meningkatkan kualitas pakan adalah pemanfaatan mikroba yang dikenali sebagai metode GRAS (Generally Recognized as Safe) seperti Saccharomycetes cerevisiae dan Torula sebagai alternatif sumber protein, asam amino, dan asam-asam lemak esensial. Pemanfaatan mikroba tersebut dilakukan melalui penambahan mikroba secara langsung ke dalam bahan pakan, atau ditambahkan sebagai pre feeding process atau feed preparation karena mikroba tersebut berperan dalam perbaikan pakan melalui proses fermentasi dengan menguraikan materi pakan yang sulit dicerna hewan budidaya, mendetoksikasi toksikan dalam bahan pangan, dan meningkatkan kandungan protein. Selanjutnya menurut Irianto (2003), bahwa pada budidaya, probiotik dapat berasal dari bakteri, yeast, mikroalga, serta bakteriofag, namun apabila meto de GRAS harus diterapkan pada probiotik budidaya, tentu strain-strain semacam Pseudomonas dan V. alginolyticus harus ditolak, karena kriteria dari sisi usaha budidaya menjadi tidak sepenuhnya aman.

Ada dua macam cara aplikasi probiotik yaitu: 1) melalui lingkungan (air dan dasar tambak) dan 2) melalui oral (dicampurkan ke dalam pakan). Aplikasi cara kedua dapat meningkatkan kualitas pakan dengan menambahkan bahan aditif berupa probiotik yang berisi mikroba pengurai ke dalam pakan yang dapat berfungsi untuk memperbaiki kualitas pakan dengan cara penguraian sehingga dapat meningkatkan kecernaan pakan. 


\section{HASIL PENGGUNAAN PROBIOTIK}

Tangko et al. (2007) menggunakan probiotik H-S, pada keramba jaring apung ukuran $1 \mathrm{~m} \times 1 \mathrm{~m} \times 1,2 \mathrm{~m}$ yang terbuat dari jaring polietilen dengan ukuran mata jaring 1,5 inci (Gambar 1).

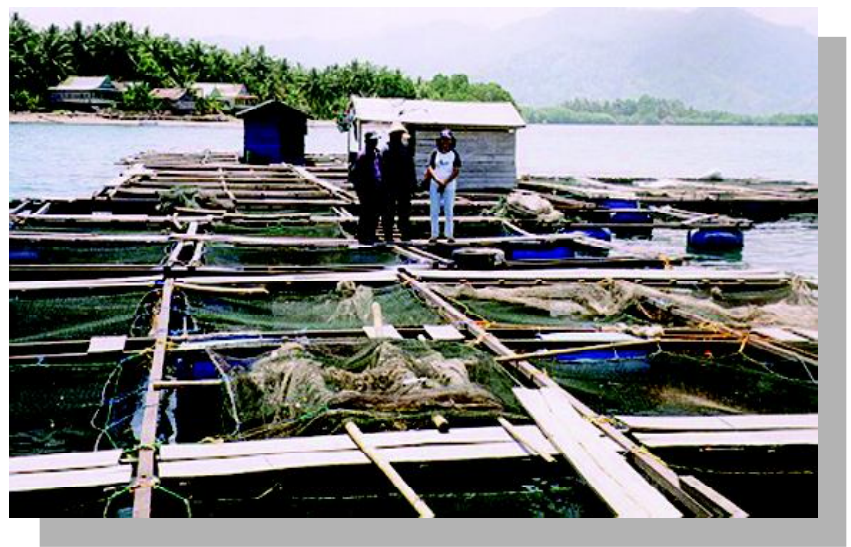

Gambar 1. Keramba jaring apung (KJA) di laut untuk budidaya bandeng

Masing-masing keramba diisi dengan ikan bandeng, ukuran 90--100g/ekor sebanyak 25 ekor dan ditempatkan pada sebuah rakit dengan bagian yang tidak terendam $20 \mathrm{~cm}$ dari permukaan sehingga volume keramba adalah $1 \mathrm{~m}^{3}$.

Sebagai perlakuan adalah konsentrasi probiotik H-S dicampurkan kedalam pakan yaitu: A kontrol tanpa probiotik $(0,0 \%) ; \mathrm{B}(0,1 \%) ; \mathrm{C}(0,2 \%)$ dan $\mathrm{D}(0,3 \%) \mathrm{kg}$ pakan dengan ulangan tiga kali. Probiotik diberikan dengan cara mencampur secara merata dengan pakan (Gambar 2), kemudian dicetak dengan menggunakan mesin pencetak pakan, selanjutnya dikeringkan hingga siap diberikan kepada hewan uji. Pemberian pakan dilakukan 2 kali sehari pada pagi dan sore hari secara satiasi. Adapun analisis proksimat pakan uji dapat dilihat pada Tabel 2.
Hasil penelitian menunjukkan bahwa dosis 0,2\%/kg pakan pada budidaya bandeng (Gambar 3) dengan sistem keramba jaring apung memberikan respons yang terbaik terhadap laju pertumbuhan harian, rasio konversi pakan, dan kecernaan pakan baik bahan kering, protein, maupun energi (Tabel 3 dan 4). Kisaran nilai beberapa variabel kualitas air yang diukur selama penelitian masih berada dalam batas-batas yang layak untuk menunjang pertumbuhan ikan uji (Tangko et al., 2007).

Secara deskriptif, penampilan ikan bandeng yang telah diberi probiotik H-S dengan yang tidak diberi probiotik dari hasil budidaya tambak adalah hampir sama, namun mempunyai keunggulan komparatif seperti tekstur ikan yang lebih kompak, bau, dan rasa lebih gurih dibandingkan dengan yang dibudidayakan di tambak.

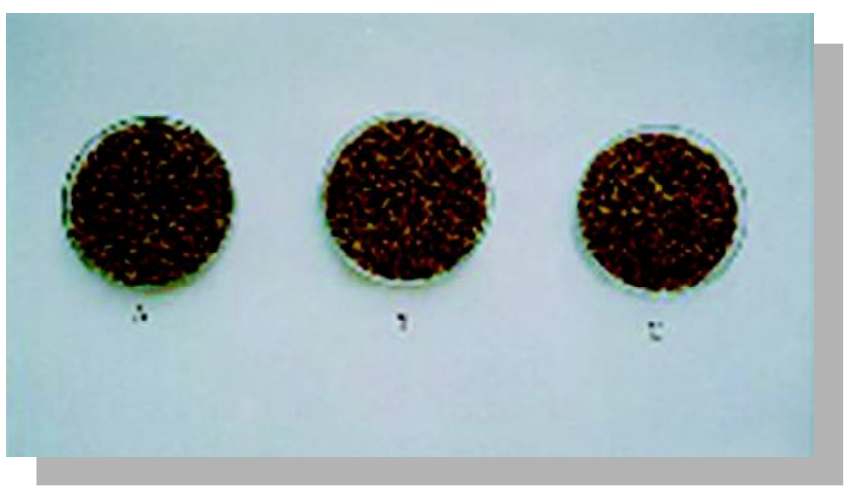

Gambar 2. Hasil cetakan pakan yang telah dicampur probiotik H-S

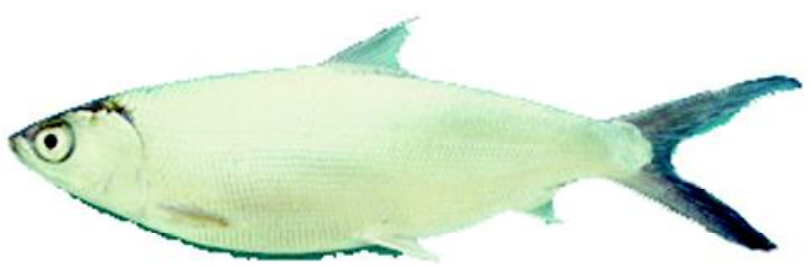

Gambar 3. Penampilan ikan bandeng dari KJA laut

Tabel 2. Analisis proksimat pakan yang dicobakan selama penelitian

\begin{tabular}{|c|c|c|c|c|}
\hline \multirow{2}{*}{$\begin{array}{c}\text { Komposisi } \\
(\%)\end{array}$} & \multicolumn{4}{|c|}{ Perlakuan H-S (\%kg pakan) } \\
\hline & $\mathrm{A}(0,0 \%)$ & B $(0,1 \%)$ & $C\left(0,2^{\circ}\right)$ & D $(0,3 \%)$ \\
\hline Protein & 29,40 & 29,80 & 29,50 & 29,40 \\
\hline Lemak & 13,80 & 13,60 & 13,60 & 13,60 \\
\hline Abu & 11,80 & 12,10 & 12,10 & 11,90 \\
\hline Air & 2,90 & 3,30 & 3,70 & 3,10 \\
\hline Nitrogen bebas ekstrak & 44,70 & 44,43 & 44,65 & 44,91 \\
\hline Serat kasar & 0,23 & 0,07 & 0,15 & 0,19 \\
\hline Energi (kal/g) & $4.908,40$ & $4.872,60$ & $4.295,90$ & $4.985,60$ \\
\hline
\end{tabular}

Sumber: Laboratorium Nutrisi BRPBAP Maros (2001) 
Tabel 3. Laju pertumbuhan harian, sintasan, dan rasio konversi pakan pada budidaya ikan bandeng selama percobaan

\begin{tabular}{lcccc}
\hline \multirow{2}{*}{ Parameter } & \multicolumn{4}{c}{ Perlakuan H-S (\%/kg pakan) } \\
\cline { 2 - 5 } & $\mathbf{A ~ ( 0 , 0 \%}$ & $\mathbf{B ~ ( 0 , 1 )}$ & $\mathbf{C ~ ( 0 , 2 \% )}$ & $\mathbf{D ~ ( 0 , 3 \% )}$ \\
\hline Lama pemeliharaan (hari) & 56 & 56 & 56 & 56 \\
Bobot awal (g/ind.) & 104,3 & 89,7 & 96,6 & 92,3 \\
Bobot akhir (g/ind.) & 193,5 & 179,6 & 225,8 & 195,2 \\
Laju pertumbuhan harian (g/ind.) & $1,1^{\mathrm{a}}$ & $1,2^{\mathrm{a}}$ & $1,6^{\mathrm{b}}$ & $1,3^{\mathrm{a}}$ \\
Sintasan (\%) & $98,6^{\mathrm{a}}$ & $100,0^{\mathrm{a}}$ & $97,3^{\mathrm{a}}$ & $98,6^{\mathrm{a}}$ \\
Rasio konversi pakan (FCR) & $2,4^{\mathrm{a}}$ & $1,9^{\mathrm{ab}}$ & $1,3^{\mathrm{c}}$ & $1,6^{\mathrm{bc}}$ \\
\hline
\end{tabular}

Catatan: Nilai dalam baris yang sama dan diikuti oleh huruf yang sama tidak berbeda nyata Sumber: Tangko et al. (2007)

Tabel 4. Koefisien kecernaan bahan kering, protein, dan energi pada budidaya bandeng selama percobaan

\begin{tabular}{cccc}
\hline \multirow{2}{*}{ Perlakuan } & \multicolumn{3}{c}{ Koefisien kecernaan (\%) } \\
\cline { 2 - 4 } & Bahan kering & Protein & Energi \\
\hline A $(0,0 \%)$ & $13,95 \pm 6,47^{\mathrm{c}}$ & $49,19 \pm 4,46^{\mathrm{b}}$ & $40,24 \pm 4,53^{\mathrm{c}}$ \\
B $(0,1 \%)$ & $36,30 \pm 3,12^{\mathrm{a}}$ & $54,93 \pm 5,48^{\mathrm{ab}}$ & $55,17 \pm 2,04^{\mathrm{ab}}$ \\
C $(0,2 \%)$ & $40,30 \pm 3,49^{\mathrm{a}}$ & $61,03 \pm 0,21^{\mathrm{a}}$ & $58,91 \pm 6,16^{\mathrm{a}}$ \\
D $(0,3 \%)$ & $24,28 \pm 6,60^{\mathrm{b}}$ & $53,93 \pm 2,27^{\mathrm{b}}$ & $50,02 \pm 3,49^{\mathrm{b}}$ \\
\hline
\end{tabular}

Catatan: Nilai dalam kolom yang sama dan diikuti oleh huruf yang sama tidak berbeda nyata

Sumber: Tangko et al. (2007)

Dari Tabel 3 dan 4 dapat dijelaskan bahwa konsentrasi $0,2 \% \mathrm{~kg}$ pakan yang diberikan pada hewan uji ikan bandeng memberikan respons yang terbaik terhadap laju pertumbuhan harian, rasio konversi pakan, dan kecernaan pakan baik bahan kering, protein, maupun energi sebagai akibat dari aktivitas mikroorganisme Lactobacillus di dalam memperbaiki mutu pakan.

\section{KESIMPULAN}

Untuk meningkatkan kualitas pakan adalah pemanfaatan mikroba yang dikenali sebagai metode GRAS (Generally Recognized as Safe). Pemanfaatan mikroba tersebut dilakukan melalui penambahan mikroba secara langsung kedalam bahan pakan, namun apabila metode GRAS harus diterapkan pada probiotik budidaya, tentu tidak semua strain-strain mikroba dapat dimanfaatkan misalnya Pseudomonas dan V. alginolyticus, karena kriteria dari sisi usaha budidaya menjadi tidak sepenuhnya aman. Salah satu jenis probiotik dengan merek dagang H-S mengandung bakteri Lactobacillus dengan konsentrasi 0,2\%per kg pakan yang diberikan pada hewan uji ikan bandeng pada KJA laut dapat dipertimbangkan untuk digunakan karena memberikan respons yang terbaik terhadap laju pertumbuhan harian, rasio konversi pakan, dan kecernaan pakan baik bahan kering, protein, maupun energi.

\section{DAFTAR PUSTAKA}

Ahmad, T., Rachmansyah, and N.N. Palinggi. 2000. The availability and use of fish feed local ingredients for humpback grouper grow-out. Proceeding of Regional Workshop on Management Strategies for Sustainable Sea Farming and Grouper Aquaculture. NACA, Bangkok, Thailand. $48 \mathrm{pp}$.

Buckle, K.A., R.A. Edward, G.H. Fleet, and M. Wootton. 1987. Ilmu Pangan. Penerbit Universitas Indonesia. Jakarta. 623 pp.

Fuller, R. 1987. A Review, Probiotics in man and animal. Journal of Applied Bacteriology. 66: 365-378.

Irianto, A. 2003. Probiotik Akuakultur. Cetakan I. Penerbit Gadjah Mada University Press. Bulaksumur Yogyakarta. $125 \mathrm{pp}$.

Irianto, A. 2004. Percepatan pencapaian sasaran teknologi perikanan budidaya melalui peran mikrobiologi dan bioteknologi. Disampaikan pada Rapat Kerja Teknis Pusat Riset Perikanan Budidaya. Jogyakarta. 29- 30 November 2004. 9 pp.

Khasani, I. 2007. Aplikasi probiotik menuju sistem budidaya perikanan berkelanjutan. M edia Akuakultur. 2(2): 86- 90 .

Laining, A. dan Rachmansyah. 2002. Komposisi nutrisi beberapa bahan baku lokal dan nilai kecernaan proteinnya pada ikan kerapu bebek, Cromileptisaltivelis. J. Pen. Perik. Indonesia, edisi Akuakultur. 8(2): 45- 51.

Palinggi, N.N. 1993. Pengaruh pergantian bungkil kedelai dengan ragi terhadap pertumbuhan pasca larva udang windu. Tesis Program Pasca Sarjana. Institut Pertanian 
Bogor. (Tidak diterbitkan). 57 pp.

Salminen, S., A. Ouwehand, Y. Benno, and Y.K. Lee. 1999. Probiotics: how should be defined?. Trends in food Science and Technology. 10: 107-110.
Tangko, A.M., A. Mansyur, dan Reski. 2007. Penggunaan probiotik pada pakan pembesaran ikan bandeng dalam keramba jaring apung di laut. J. Ris. Akuakultur. 2(1): $33-40$. 